\title{
Reflections on Chinese Zombie Enterprises From the Perspective of Nash Equilibrium Theory
}

\author{
Shiqi Zhang ${ }^{1}$ \\ ${ }^{1}$ Shanghai Maritime University, Shanghai, China \\ Correspondence: Shiqi Zhang, Shanghai Maritime University, Shanghai, China.
}

Received: January 2, 2019

Accepted: January 10, 2019

Online Published: January 18, 2019

doi:10.20849/abr.v4i1.539

URL: https://doi.org/10.20849/abr.v4i1.539

\begin{abstract}
This paper gives the game analysis on zombie enterprises, banks and governments using Nash equilibrium theory in order to explore how to break the predicament of Chinese zombie enterprises. The optimal scheme is that the government does not provide subsidies for zombie enterprises, banks do not offer loans for zombie enterprises, and zombie enterprises apply for bankruptcy liquidation. Then According to the conclusions, put forward relevant policy suggestions to the government, banks and zombie enterprises.
\end{abstract}

Keywords: nash equilibrium, zombie enterprises, game analysis

\section{Introduction}

In recent years, along with the domestic economic downturn, the non-performing loan rate of banks has gradually increased, and zombie enterprises, one of the debtors of these non-performing loans, have gradually become a major factor affecting economic recovery. Zombie enterprises refer to debt companies that can't regain profitability on their own, but are exempt from bankruptcy because of the support of lenders or governments.

China has tried to introduce some policies to curb the existence of zombie companies, such as the supply-side reforms introduced in 2015, emphasizing "three eliminations, one reduction, and one supplement", among which the "three eliminations" includes removing excess capacity, aiming to improve the structure of zombie enterprises and promote mergers and acquisitions and bankruptcy liquidation of zombie enterprises. However, after the implementation of the reform, the current situation is not changed significantly, and many zombie enterprises are still standing firm. This is mainly due to the huge obstacles caused by the game relationship between multi-stakeholders. The government continues to provide subsidies for zombie enterprises in consideration of factors such as maintaining stability in employment and promoting stable growth of national economic income. From the perspective of the bank, on the one hand, due to the government's standing background, banks have relaxed requirements for credit approval for zombie enterprises. On the other hand, since the zombie enterprise is bound to the bank, once the bank terminates the loan, the non-performing loan ratio of bank will be quickly exposed, so the bank have to continue to provide loans to zombie companies, which result in vicious circle.

Generally speaking, the Chinese government, banks and zombie enterprises are extremely closely related, and they have a chain reaction just like the domino effect. The existence of zombie enterprises has caused tremendous waste of resources to market economy, aggravated financial risks, and it is imperative to dispose of zombie enterprises. Therefore, in order to solve the problem of zombie enterprises, the game relationship between the government, banks and zombie enterprises should be handled well. This paper explains the game relationship between the three by means of Nash equilibrium theory, and explains the reasons why the conclusion is contrary to reality. Finally, it provides policy suggestions on how to solve the problem of zombie enterprises.

\section{Nash Equilibrium Analysis}

\subsection{Model Hypothesis}

Suppose that the normal operating revenue of zombie enterprise $\mathrm{E}$ is $\mathrm{R}$ in the case of sufficient funds and 0 in the case of bankruptcy. The total cost of maintaining the operation of zombie enterprises is $\mathrm{C}$. The government makes a decision on whether to subsidize the enterprises by observing the operation status and reputation of zombie enterprises. If the government subsidizes the zombie enterprises, the subsidy is recorded as $\mathrm{S}$. Then the 
bank makes the decision to lend or not to the zombie enterprises by observing the government's decision-making. If a bank makes a decision to lend to an enterprise, it will record the principal of the loan as I, the interest on the loan as $r$. Bank loans to zombie enterprises benefit from the government for a, and losses from losing loans to other enterprises are recorded as beta. In the case of bankruptcy liquidation, the value of non-current assets of zombie enterprise is $\mathrm{V}$.

\subsection{Dynamic Game Model}

According to Nash equilibrium theory, using backward induction, along the opposite direction of the game order, we gradually find out the decision-making with the highest profit for each participant in the decision-making knot, and carry on the reverse deduction to the first decision-making knot of the game.

\subsubsection{From the Perspective of Zombie Enterprises}

(1) When zombie enterprise apply for bankruptcy liquidation, and whether the government provides subsidies or whether banks offer loans or not, the zombie enterprise will repay their debts with all the assets they have, with income of 0 .

(2) When the government provides subsidies, banks offer loans and zombie enterprises maintain normal operations, part of the income of zombie enterprises come from the profits of normal operation of enterprises, and the other part is the subsidies of the government. The total income is R-C+S-r.

(3) When the government provides subsidies, banks do not offer loans, and zombie enterprises continue to maintain its operations with difficulty, the income of enterprises is $-\mathrm{C}+\mathrm{S}$.

(4) When the government does not provide subsidies, banks offer loans and zombie enterprises continue to operate, the income of enterprises is R-C-r.

(5) When the government does not provide subsidies, the bank does not offer loans, and the zombie enterprise continue to maintain its operations with difficulty, the income of enterprises is -C.

\subsubsection{From the Perspective of Banks}

(1) When the government provides subsidies, banks offer loans, and zombie enterprises apply for bankruptcy liquidation, the bank's income comes from the non-current assets of the bankruptcy liquidation of the zombie enterprise and the positive effect of the government on the bank, deducting the sunk costs that the zombie enterprise can't repay. The income is V+ $\alpha$-I-r.

(2) When the government provides subsidies, banks offer loans, and zombie enterprises maintain normal operations, the income of banks is the interest that can be afforded by the normal operation of enterprises and the positive effect of the government on banks, which is $\alpha+r$.

(3) When the government provides subsidies, banks does not offer loans, and zombie enterprises apply for bankruptcy liquidation, at the same time that the bank lost its sunk costs, it also obtained the proceeds from providing loans to high-energy enterprises and the illiquid assets of bankruptcy liquidation of the zombie enterprises. The total income is V-I-r+ $\beta$.

(4) When the government provides subsidies, banks do not offer loans, and zombie enterprises continue to maintain its operations with difficulty, the bank's income is $r+\beta$.

(5) When the government does not provide subsidies, banks offer loans, and zombie enterprises apply for bankruptcy liquidation, the bank's income is V-I-r.

(6) When the government does not provide subsidies, banks offer loans, and zombie enterprises continue to operate, the bank's income is $\mathrm{r}$.

(7) When the government does not provide subsidies, banks do not offer loans, and zombie enterprises apply for bankruptcy liquidation, the bank's income is V-I-r+ $\beta$.

(8) When the government does not provide subsidies, the bank does not lend, and zombie enterprises continue to maintain its operations with difficulty, the bank's income is $r+\beta$.

\subsubsection{From the Perspective of the Government}

(1) When the government provides subsidies, banks offer loans and zombie enterprises apply for bankruptcy liquidation, the government lost the subsidy amount and then the government income is -S.

(2) When the government provides subsidies, banks offer loans, and zombie enterprises continue to maintain normal operations, the zombie enterprises have produced economic benefits, so the government income is R-S. 
(3) When the government provides subsidies, banks do not offer loans, and zombie enterprises apply for bankruptcy liquidation, the government income is -S.

(4) When the government provides subsidy subsidies, banks do not offer loans, and zombie enterprises continue to maintain its operations with difficulty, the government income is -C-S.

(5) When the government does not provide subsidies, banks offer loans and zombie enterprises apply for bankruptcy liquidation, the government has no income, which is 0 .

(6) When the government does not provide subsidies, banks offer loans, and zombie enterprises continue to operate, the government income is R-C.

(7) When the government does not provide subsidies, banks do not offer loans, and the zombie enterprises apply for bankruptcy liquidation, the government income is zero.

(8) When the government does not provide subsidies, banks do not offer loans, and zombie enterprises continue to maintain its operations with difficulty, the government revenue is $-\mathrm{C}$.

The summary is shown in the following table:

\begin{tabular}{cccc}
\hline Situations & Zombie Enterprises & Bank & Government \\
\hline G-S,B-L,E-NO & 0 & V $+\alpha-\mathrm{I}-\mathrm{r}$ & $-\mathrm{S}$ \\
\hline G-S,B-L,E-O & R-C+S-r & $\alpha+\mathrm{r}$ & $\mathrm{R}-\mathrm{S}$ \\
\hline G-S,B-NL,E-NO & 0 & $\mathrm{~V}-\mathrm{I}-\mathrm{r}+\beta$ & $-\mathrm{S}$ \\
\hline G-S,B-NL,E-O & $-\mathrm{C}+\mathrm{S}$ & $\mathrm{r}+\beta$ & $-\mathrm{C}-\mathrm{S}$ \\
\hline G-NS, B-L,E-NO & 0 & $\mathrm{~V}-\mathrm{I}-\mathrm{r}$ & 0 \\
\hline G-NS, B-L,E-O & R-C-r & $\mathrm{r}$ & $\mathrm{R}-\mathrm{C}$ \\
\hline G-NS, B-NL,E-NO & 0 & $\mathrm{~V}-\mathrm{I}-\mathrm{r}+\beta$ & 0 \\
\hline G-NS, B-NL,E-O & $-\mathrm{C}$ & $\mathrm{r}+\beta$ & $-\mathrm{C}$
\end{tabular}

Note: G-S refers that the government provides subsidies, G-NS refers to the government does not provide subsidies, B-L refers to banks offer loans, B-NL refers to banks do not offer loans, E-O refers to zombie enterprises continue to operate, E-NO refers to zombie enterprises apply for bankruptcy liquidation.

\subsection{Game Analysis}

First, analyze the zombie enterprise, for the situation (2), R-C+S-r $>0$; for the situation (3), because the government subsidies to the zombie enterprise generally do not exceed the cost of the normal operation of the zombie enterprise $\mathrm{C}$, so $-\mathrm{C}+\mathrm{S}<0$; For the situation (4), only bank loans are insufficient to meet the normal operation of the company, so R-C-r $<0$; for the case (5), -c $<0$. In response to the situation (1), the zombie enterprise chooses to go bankrupt, and then the income is zero. Therefore, in this decision-making, the optimal choice for the zombie enterprise is: $\{(G$ provide subsidies, B offer loans, $E$ maintain operation $)$, (G provide subsidies, B do not offer loans, E go bankrupt), (G provide subsidies, B offer loans, E go bankrupt), (G do not provide subsidies, $\mathrm{B}$ offer loans, $\mathrm{E}$ go bankrupt), ( $\mathrm{G}$ do not provide subsidies, B do not offer loans, E go bankrupt)\}.

Second, analyze the bank, because zombie enterprises are generally heavy-asset enterprises, so when the bank chooses the optimal decision, the non-liquid assets V is large, so V-1+r $+\beta>\mathrm{V}-\mathrm{I}-\mathrm{r}+\alpha>\alpha+\mathrm{r}$, the bank will choose the situation of (3)or (7), that is, the bank's best decision is $\{(\mathrm{G}$ provide subsidies, B do not offer loans, E go bankrupt), (G do not provide subsidies, B do not offer loans, E go bankrupt)\}.

Third, analyze the government, because $-\mathrm{s}<0$, the government will eventually choose option (7), that is, the government's optimal strategy is $\{(\mathrm{G}$ do not provide subsidies, B do not offer loans, E go bankrupt $)\}$.

According to the above results, the Nash equilibrium is $\{(\mathrm{G}$ do not provide subsidies, B do not offer loans, E go bankrupt) $\}$, that is, the government do not provide subsidies for zombie enterprises, banks do not offer loans to zombie enterprises, and zombie enterprises go bankrupt. 


\section{Reasons for Inconsistency Between the Theory and Practice}

According to Nash equilibrium analysis, the optimal scheme is that the government does not provide subsidies for zombie enterprises, banks do not offer loans to zombie enterprises, and zombie enterprises apply for bankruptcy liquidation. However, in China's reality, the government often provides convenient conditions for zombie enterprises, such as provides subsidies to them from time to time, and indirectly puts pressure on banks to offer loans to zombie enterprises. The problems of zombie enterprises are much more complicated than expected.

As far as the government is concerned, it is willing to provide subsidies for zombie enterprises for the purpose of "maintaining stability". The main reasons are as follows: Firstly, most of the zombie enterprises in China are large-scale manufacturing enterprises, which can solve the employment problem of part of the Chinese population to a certain extent. Once the zombie enterprises close down, China will lose many employment opportunities, produce various labor disputes and then affect social stability. Secondly, there are usually a large number of associations between the zombie enterprises and the government, the upstream and downstream relations of the industry, and the mutual protection relationship. Once the zombie enterprises fail, they will have a major impact on the local economic and financial environment. Thirdly, in some areas, some large-scale zombie enterprises have basically assumed the national economic income of the entire region, and thus become a large taxpayer in a certain region, making great contributions to the local economic development. Once these enterprises fail, local tax revenue will be straight. The decline will lead to a series of serious social problems such as public infrastructure and poverty subsidies.

On the bank side, banks are also willing to lend to zombie companies for two reasons. First, the government has increased trust for zombie companies and provided bank guarantees for enterprises. Therefore, when banks issue loans to large state-owned enterprises and even zombie enterprises, there will be government guarantees, no possibility of default, no credit risk, then there is no need to give priority to loans to companies other than state-owned enterprises. In recent years, the rise in real estate and other asset prices has allowed zombie enterprise loans to be repaid and the rise in asset prices has allowed banks to renew their loans. Second, zombie companies kidnap banks, and once they terminate the loan, they will lead to rapid exposure of non-performing loans. Since the scale of loans of zombie enterprises is generally large, once the loans are not renewed, the bank's non-performing rate may accelerate. In addition, because the general liquidation value of zombie corporate assets is already very low, banks will be more hopeful that the company will recover from the government's rescue, and the recovery rate may be higher than direct liquidation.

As far as zombie enterprises are concerned, with the two pillars of the government and banks as the backstage, the zombie enterprises can stand up. The zombie enterprises survive by the natural advantages of capital and credit, and they are unwilling to worry about production efficiency and economic benefits. In other words, they are losing the original vigor and vitality, and gradual move toward dilemma under these unique conditions.

\section{Policy Suggestions}

The reality is contrary to the conclusions drawn by Nash equilibrium theory, which leads to many adverse economic consequences: the existence of zombie enterprises not only makes the national resources flow to these sunset enterprises, resulting in huge waste of resources, but also engulfs bank credit, hinders the development of those high-tech industries that really need funds, which has a negative effect on the creation of huge national wealth. On this basis, in view of the problem of rescuing zombie enterprises, the author puts forward relevant policy recommendations from the perspective of Chinese government, banks and enterprises.

\subsection{From the Perspective of the Government}

The government plays a crucial role in obtaining loans for zombie enterprises to continue to operate. Therefore, the government should change its mindset, it should not only be aware of the long-term economic harm of zombie enterprises, but also should rationally take bankruptcy law as the benchmark, constantly improve the social security mechanism, stop subsidizing zombie enterprises, reduce intervention, and let zombie enterprises exit normally. In addition, the government should redistribute resources and put the resources once invested in zombie enterprises into industries that can really promote the development of national economy in a rational and orderly manner. At the same time, the disposal of zombie enterprises will bring some negative impacts, which will affect many relevant departments and the original economic order. The government must make efforts to do a good job of appeasing people and minimize people's losses.

\subsection{From the Perspective of Banks}

Banks should strengthen risk monitoring and early warning of zombie enterprises. Banks should not only be 
familiar with the assets and liabilities of enterprises, the development of industries of the target enterprise but also evaluate the collateral accurately and impartially, strengthen the censorship of the risk, accurately estimate the capital needs of enterprises in many aspects. It is very important that banks should maintain independence in making lending decisions. At the same time, banks need to improve their ability to deal with the bankruptcy of zombie enterprises. Banks can prevent enterprises from evading debts and protect their rights and interests through bankruptcy law, so as to realize the right to repay according to law. When a zombie enterprise goes bankrupt, the bank should also set up a special group to conduct an in-depth investigation of the assets that can be liquidated by the enterprise, guard the assets of the enterprise during the liquidation process to prevent the illegal transfer of the assets, in order to protect the credit assets to the maximum extent.

\subsection{From the Perspective of Zombie Enterprises}

The managers of zombie companies need to change their own ideas, and realize the inefficiency of high financial costs matching with low profit margins, which will only lead to a greater debt burden in the long run. Zombie enterprises should have a clear understanding of bankruptcy law, bankruptcy system and enforcement methods. Enterprises should establish the ideology of self-financing profits and losses, avoid blindly optimistic investment, blindly expand, and over-investment. At the same time, zombie enterprises can transfer market positioning reasonably, if possible into high-tech industries, investing funds in market analysis and product development, constantly improving their scientific and technological strength, and developing new high-tech products to attract consumers, thereby expanding product demand space.

\section{Summary}

To sum up, the government, banks and zombie enterprises all bear certain responsibilities under the background of marketization. The zombie enterprises themselves should locate themselves accurately, establish bankruptcy consciousness and carry out rational self-rescue. While encouraging enterprises to innovate and guide enterprises, the government should avoid excessive interference, give full play to the role of market survival of the fittest, let the zombie enterprises make their own choices and assume corresponding responsibilities. Banks should have their own judgment, make loan assessment according to the actual situation, and strengthen risk monitoring. As for the existence of zombie enterprises, we can not generalize, we should identify the problem, pinpoint the direction, and combine the actual problem with the right medicine. Only by properly handling the interests between enterprises, banks and the government and seeking the best solution, can the market economy develop well and rapidly.

\section{References}

Du, W., \& Li, M. (2019). Can environmental regulation promote the governance of excess capacity in China's energy sector? The market exit of zombie enterprises. Journal of Cleaner Production. https://doi.org/10.1016/j.jclepro.2018.09.267

Wang, J. (2016). Hunting Zombie Companies. BeijingReview.

Zhang, Q. (2013). Current Situation and Countermeasure of Overcapacity in China. Macroeconomic Management.

Zhao, Y, \& Pu, Y. (2010). Game Theory and Economic Model. China People's University Press.

Zhu, Z., \& Yegneswaran, V., \& Chen, Y. (2009). Using failure information analysis to detect enterprise zombies. Lecture Notes of the Institute for Computer Sciences, Social-Informatics and Telecommunications Engineering. https://doi.org/10.1007/978-3-642-05284-2_11

\section{Copyrights}

Copyright for this article is retained by the author(s), with first publication rights granted to the journal.

This is an open-access article distributed under the terms and conditions of the Creative Commons Attribution license (http://creativecommons.org/licenses/by/4.0/). 